\title{
Evaluasi Karakter Kualitatif dan Kuantitatif 20 Genotipe Cabai Rawit Merah (Capsicum frutescens L.) Koleksi IPB
}

\author{
Evaluation of Qualitative and Quantitative Characters \\ 20 Genotypes Of Bird Pepper (Capsicum frutescens L.) IPB Collection
}

\author{
Abdul Hakim', Muhamad Syukur²*, Yudiwanti Wahyu² \\ ${ }^{1}$ Mahasiswa Sekolah Pascasarjana Program Studi Pemuliaan dan Bioteknologi Tanaman, Institut Pertanian Bogor. \\ ${ }^{2}$ Departemen Agronomi dan Hortiultura, Fakultas Pertanian, Institut Pertanian Bogor \\ Jl. Meranti Kampus IPB Darmaga, Bogor 16680. Phone./Fax 0251-8629448
}

Diterima 8 Januari 2018/Disetujui 24 Januari 2018

\begin{abstract}
Bird pepper (Capsicum frutescens L.) is one of the leading commodities of horticulture in Indonesia and of the most potential vegetables to be developed. The aimed of this research is to evaluate qualitative and quantitative character (Capsicum frutescens L.) and analysis cluster. Plant material used are 20 genotypes of bird pepper. The experiment was arranged in Randomized Complete Block Design (RCBD) single factor with three replications. The results showed that IPB $C 341$ the genotype that had the highest weight per fruit and yield. IPB C350 was a genotype had the longest fruit size. IPB C337 was the genotype with the largest number of fruit per plant. The results of the analysis cluster divided into 4 groups. Group 1 there were 2 genotypes there were IPB C190 and IPB C 289. Group 2 consists of 6 genotypes there were IPB C285, IPB C295, IPB C321, IPB C349, IPB C290 and IPB C348. Group 3 consists of 6 genotypes there were IPB C331, IPB C332, $I P B$ C334, IPB C334, IPB C344, IPB C335 and IPB C337, IPB C339 and group 4 consists of 6 genotypes there were IPB C342, IPB C350, IPB C339, IPB C345, IPB C341 and IPB C343.
\end{abstract}

Key words: cluster analysis, genotipes, yield

\section{ABSTRAK}

Cabai rawit merah (Capsicum frutescens L.) adalah salah satu komoditas unggulan hortikultura di Indonesia dan merupakan salah satu jenis sayuran yang sangat berpotensi untuk dikembangkanPenelitian ini bertujuan untuk melakukan evaluasi karakter kualitatif dan kuantitatif (Capsicum frutescens L) serta analisis gerombol. Bahan tanaman yang digunakan sebanyak 20 genotipe cabairawit merah.Percobaan disusun dalam rancangan kelompok lengkap teracak (RKLT) faktor tunggal dengan 3 ulangan. Hasilnya menunjukkan Genotipe IPB C341 merupakan genotipe yang mempunyai bobot per buah dan bobot buah per tanaman paling besar. IPB C350 merupakan genotipe yang memiliki ukuran buah paling panjang. IPB C337 merupakan genotipe dengan jumlah buah per tanaman paling banyak. Hasil analisis gerombol membagi ke dalam 4 kelompok yaitu \%. Kelompok 1 terdapat 2 genotipe yaitu IPB C190 dan IPB C 289. kelompok 2 terdiri dari 6 genotipe IPB C285, IPB C295, IPB C321, IPB C349, IPB C290 dan IPB C348. kelompok 3 terdiri dari 6 genotipe yaitu IPB C331, IPB C332, IPB C334, IPB C334, IPB C344, IPB C335 dan IPB C337, IPB C339, kelompok 4 terdiri dari 6 genotipe yaitu IPB C342, IPB C350, IPB C339, IPB C345, IPB C341 dan IPB C343.

Kata kunci :analisis gerombol,genotipe, hasil

\section{PENDAHULUAN}

Cabai rawit (Capsicum frutescens L.) adalah salah satu komoditas unggulan hortikultura di Indonesia dan merupakan salah satu jenis sayuran yang sangat berpotensi untuk dikembangkan. Jenis cabai rawit yang dikenal di

\footnotetext{
* Penulis untuk korespondensi. e-mail: muhsyukur.ipb.ac.id
}

Indonesia yaitu cabai rawit yang termasuk dalam Capsicum annuum L dan Capsicum frutescens $\mathrm{L}$. Menurut Undang et al. (2015) cabai rawit spesies $C$. annuит L. memiliki warna mahkota (corolla) putih dan ungu, warna anter biru dan ungu, warna buah muda hijau, ungu, putih kehijauan, dan kuning kehijauan, tangkai buah mengikuti bentuk pangkal buah dan tidak ada penyempitan, bentuk daun lanceolate dan ovate, sedangkan cabai rawit spesies $C$. frutescens $\mathrm{L}$. hanya memiliki warna mahkota (corolla) hijau keputihan, 
warna anter biru, warna buah muda hijau, putih, dan putih kehijauan, tangkai buah mengecil atau menyempit pada bagian pangkal buah, bentuk daun deltoid. Sun et al. (2014) menyatakan ada sekitar 30 spesies dalam genus Capsicum, lima diantaranya sudah dibudidayakan yaitu spesies Capsicum annuum L., Capsicum baccatum L., Capsicum chinense Jacq, Capsicum frutescens L. dan Capsicum pubescens Ruiz et Pav.

Produktivitas cabai rawit di Indonesia pada tahun 2014 sekitar 5.93 ton ha-1 (BPS dan Dirjen Horti, 2014), sedangkan potensi cabai rawit bisa mencapai 12-20 ton ha $^{-1}$ (Sujinto dan Dianawati, 2015). Produktivitas cabai rawit di Indonesia masih rendah. Salah satu penyebabnya adalah petani belum banyak menggunakan varietas unggul berdaya hasil tinggi. Produktivitas cabai rawit masih dapat ditingkatkan melalui kegiatan pemuliaan tanaman melalui proses perakitan varietas. Tahap awal dalam kegiatan perakitan varietas ini adalah mengkolesksi plasma nutfah dan dilakukan karakterisasi untuk mendapatkan informasi mengenai karater kualitatif maupun kuantitatif. Hill et al. (2013) menyatakan untuk meningkatkan program pemuliaan dan berkontribusi untuk sumber daya genetik tanaman cabai diperlukan karakterisasi yang rinci mengenai keragaman cabai yang ada termasuk informasi morfologi, geografis dan molekuler. Penelitian bertujuan untuk melakukan evaluasi karakter kualitatif, kuantitatif dan analisis gerombol cabai rawit merah (Capsicum frutescens L.).

\section{BAHAN DAN METODE}

Percobaan ini dilakukan pada Juli sampai Desember 2015 bertempat di Kebun Percobaan Leuwikopo IPB. Genotipe tanaman yang digunakan adalah 20 cabai rawit (Tabel 1) koleksi Laboratorium Bagian Genetika dan Pemuliaan Tanaman Departemen Agronomi dan Hortikultura IPB yaitu IPBC190, IPBC285, IPBC289, IPBC290, IPBC295, IPBC321，IPBC332， IPBC334, IPBC335, IPBC331,IPBC337, IPBC339, IPBC341, IPBC343, IPBC344, IPBC345, IPBC342, IPBC348, IPBC349, dan IPBC350.

Percobaan di lapangan disusun dalam rancangan kelompok lengkap teracak (RKLT) faktor tunggal dengan 3 ulangan, masing-masing genotipe per ulangan ditanam 20 tanaman. Bibit ditanam jika telah berumur \pm 5-6 minggu, dengan ciri-ciri pertumbuhan bibit tegar, berdaun 4-5 helai, warna daun hijau dan tidak terkena hama penyakit. Pemeliharaan yang dilaksanakan adalah penyiraman, pemupukan dengan larutan NPK (16:16:16) dengan dosis 10 $\mathrm{g} \mathrm{L}^{-1}$ dan pupuk daun $5 \mathrm{~g} \mathrm{~L}^{-1}$ dilaksanakan setiap seminggu sekali, masing-masing tanaman diberi sekitar $250 \mathrm{ml}$ larutan pupuk. Pengendalian hama dan penyakit menggunakan insektisida, fungisida, dan akarisida yang diaplikasikan jika diperlukan. Pewiwilan tunas air dilaksanakan agar tanaman dapat tumbuh optimal dan pengendalian gulma dilakukan secara manual.

Tabel 1. Genotipe cabai yang digunakan

\begin{tabular}{|c|c|c|c|}
\hline No. & Nama genotipe & Kode persilangan (IPB C) & Asal \\
\hline 1 & Pekanbaru & 190 & Pekanbaru \\
\hline 2 & Cakra Putih & 285 & BISI \\
\hline 3 & Sona & 289 & CV Enno dan Co Seed \\
\hline 4 & Inul & 290 & Bumen Jaya Seed(Garut) \\
\hline 5 & Taruna & 295 & East West Seed Indonesia \\
\hline 6 & Tabasco & 321 & Amerika \\
\hline 7 & CR Bengkulu & 331 & Bengkulu \\
\hline 8 & Maluku 1 & 332 & Ambon \\
\hline 9 & Ransiki I & 334 & Papua \\
\hline 10 & Ransiki II & 335 & Papua \\
\hline 11 & Tongkat langit & 337 & Papua \\
\hline 12 & Papua & 339 & Papua \\
\hline 13 & Cr Banyuwangi & 341 & Banyuwangi \\
\hline 14 & CR Belitung & 342 & Belitung \\
\hline 15 & CR AS 3 & 343 & Cibeureum, Darmaga \\
\hline 16 & CR AS 5 & 344 & Cibeureum, Darmaga \\
\hline 17 & CR AS 4 & 345 & Cibeureum, Darmaga \\
\hline 18 & Merapi & 348 & Garuda Benih \\
\hline 19 & Mrisan Putih & 349 & Papua \\
\hline 20 & CR Cisarua & 350 & Cisarua, Bogor \\
\hline
\end{tabular}


Karakter yang diamati terdiri atas karakter kualitatif dan kuantitatifyang dirangkum dari Descriptor for Capsicum (IPGRI, 1995). Parameter kualitatif yang diamati terdapat pada Tabel 2. Karakter kuantitatif yang diamati meliputi tinggi tanaman, lebar tajuk, diameter batang, panjang daun, umur berbunga, umur panen, jumlah buah per tanaman, bobot buah per tanaman, bobot per buah, panjang buah, dan diameter buah. Analisis data yang digunakan adalah analisis gerombol (cluster analysis) menggunakan program $\mathrm{R}$ dan dan analisis Ragam atau Analisis of Variance (ANOVA) menggunakan software SAS 9.1

\section{HASIL DAN PEMBAHASAN}

\section{Karakter Kualitatif}

Tabel 3 merupakan hasil pada pengamatan untuk karakter kualitatif pada morfologi tanaman cabai rawit. Karakter pewarnaan antosianin pada hipokotil bibit (A1) teradapat pada genotipe IPB C321. Pada karakter A2 warna hipokotil secara keselurhan berwarna hijau kecuali untuk genotipe IPB C321 berwarna ungu. Karakter bentuk batang (A3) terdapat 2 bentuk yaitu silidris dan gepeng. Genotipe IPB C289 merupakan satu-satunya genotipe yang berbatang gepeng sedangkan genotipe lainnya silidris. Karakter warna daun (A4) terbagi dalam 4 kategori. Sebagian besar genotipe cabai rawit berwarna hijau. Genotipe IPB C295 warna daunnya kuning. Genotipe IPB C190 dan IPB C289 berwarna hijau tua. Genotipe IPB C 285, IPB C290, IPB C321 dan IPB C348 memiliki warna daun hijau muda. Karakter bentuk daun (A5) sebagian besar daunnya berbentuk ovate kecuali untuk genotipe IPB C331, IPB 342 dan IPB C350 memiliki bentuk daun deltoid.

Karakter jumlah bunga per axil (A6) untuk semua cabai hanya terdapay 1 bunga per axil kecuali untuk genotipe IPB C335 dan IPB C339 memiliki jumlah bunga per axilnya 2. Genotipe yang memiliki jumlah bunga per axil lebih dari satu biasanya hasilnya akan lebih banyak, namun hal ini perlu dilakukan studi pewarisannya untuk mengetahui apakah sifatnya dominan atau resesif. Genotipe ini bisa digunakan sebagai tetua untuk merakit tanaman cabai berdaya hasil tinggi.

Pada karakter warna mahkota bunga (A7) sebagian besar berwarna putih. Genotipe IPB C190 dan IPB C285 berwarna kuning muda sementara genotipe IPB C289 dan IPB C321 berwarna kuning hijau. Genotipe yang termasuk dalam kategori terdapat pewarnaan antosianin pada anther (A8) adalah genotipe IPB C289, IPB C290, IPB C321, IPB C331, IPB C332, IPB C334, IPB C335, IPB C337, IPB C339, IPB C334 dan IPB C348 sementara genotipe lainnya

Tabel 2. Karakter kualitatif pada morfologi tanaman cabai rawit

\begin{tabular}{|c|c|c|}
\hline No & Parameter kualitatif & Skor \\
\hline 1 & Pewarnaan antosianin pada hipokotil bibit (A1) & : ada (1), tidak ada (9) \\
\hline 2 & Warna hipokotil (A2) & : putih (1), hijau (2), ungu (3) \\
\hline 3 & Bentuk batang (A3) & : silindris (1), bersudut (2), gepeng (3) \\
\hline 4 & $\begin{array}{l}\text { Warna daun diamati saat } 50 \% \text { tanaman, buahnya } \\
\text { mulai masak (A4) }\end{array}$ & $\begin{array}{l}\text { kuning (1), hijau muda (2), hijau (3), hijau tua (4), ungu muda } \\
\text { : (5), ungu (6), ungu tua (7), variegate (8) }\end{array}$ \\
\hline 5 & $\begin{array}{l}\text { Bentuk daun diamati saat 50\% tanaman, buahnya } \\
\text { mulai masak (A5) }\end{array}$ & : deltoid (1), ovate (2), lanceolate (3) \\
\hline 6 & Jumlah bunga per axil (A6) & $\begin{array}{l}\text { : satu (1), dua (2), tiga atau lebih (3), banyak bunga dalam } \\
\text { satu rangkaian tapi masing-masing dalam axil tunggal } \\
\text { (fasciculate growth) (4), lainnya (misal, kultivar dgn dua } \\
\text { bunga pada axil pertama, dan satu bunga pada axil lainnya) (5) }\end{array}$ \\
\hline 7 & Warna mahkota (A7) & $\begin{array}{l}\text { putih (1), kuning muda (2), kuning (3), kuning-hijau (4), } \\
\text { ungu dengan dasar putih (5), putih dengan dasar ungu } \\
\text { (6), putih dengan tepi ungu (7), ungu (8), lainnya (9) }\end{array}$ \\
\hline 8 & Pewarnaan antosianin pada anter (A8) & : tidak ada (1), ada (9) \\
\hline 9 & $\begin{array}{l}\text { Warna anter diamati setelah mekar sebelum } \\
\text { antesis (A9) }\end{array}$ & $\begin{array}{l}\text { : putih(1), kuning (2), biru pucat (3), biru (4), ungu (5), lainnya } \\
(6)\end{array}$ \\
\hline 10 & Tepi kelopak (A10) & : keseluruhan (3), intermediet (5), dentate (7) \\
\hline 11 & Sisi kelopak (A1) & : tidak membungkus (1), membungkus (2) \\
\hline 12 & Warna buah sebelum masak (A12) & : putih kehijauan (1), kuning (2), hijau (3), ungu (4) \\
\hline 13 & Kedudukan buah (A13) & : tegak (1), horizontal (2), merunduk (3) \\
\hline 14 & Bentuk buah dalam penampang membujur (A14) & $\begin{array}{l}\text { oblate }(1), \text { circular }(2), \text { cordate }(3), \text { square }(4), \text { rectangular }(5), \\
\text { trapezoidal }(6), \text { moderately triangular }(7), \text { narrowly triangular } \\
(8), \text { hornshaped }(9)\end{array}$ \\
\hline
\end{tabular}


Hakim et al. / J. Comm. Horticulturae 2(1):20-27

Tabel 3. Karakter kualitatif pada morfologi tanaman cabai rawit

\begin{tabular}{|c|c|c|c|c|c|c|c|c|c|c|}
\hline Genotipe & A1 & A2 & A3 & A4 & A5 & A6 & A7 & A8 & A9 & A10 \\
\hline IPB C190 & tidak ada & Hijau & silidris & hijau tua & ovate & satu & kuning muda & tidak ada & kuning & keseluruhan \\
\hline IPB C285 & tidak ada & Hijau & silidris & hijau muda & ovate & satu & kuning muda & tidak ada & kuning & dentate \\
\hline IPB C289 & tidak ada & Hijau & gepeng & hijau tua & ovate & satu & kuning hijau & ada & biru pucat & keseluruhan \\
\hline IPB C290 & tidak ada & Hijau & silidris & hijau muda & ovate & satu & putih & ada & kuning & intermediet \\
\hline IPB C295 & tidak ada & Hijau & silidris & kuning & ovate & satu & putih & tidak ada & biru pucat & intermediet \\
\hline IPB C321 & ada & ungu & silidris & hijau muda & ovate & satu & kuning hijau & ada & ungu & intermediet \\
\hline IPB C331 & tidak ada & hijau & silidris & hijau & deltoid & satu & putih & ada & ungu & intermediet \\
\hline IPB C332 & tidak ada & hijau & silidris & hijau & ovate & satu & putih & ada & ungu & intermediet \\
\hline IPB C334 & tidak ada & hijau & silidris & hijau & ovate & satu & putih & ada & kuning & intermediet \\
\hline IPB C335 & tidak ada & hijau & silidris & hijau & ovate & dua & putih & ada & biru pucat & intermediet \\
\hline IPB C337 & tidak ada & hijau & silidris & hijau & ovate & satu & putih & ada & biru pucat & interm \\
\hline IPB C339 & tidak ada & hijau & silidris & hijau & ovate & dua & putih & ada & kuning & intermediet \\
\hline IPB C341 & tidak ada & hijau & silidris & hijau & ovate & satu & putih & tidak ada & kuning & diet \\
\hline IPB C342 & tidak ada & hijau & silidris & hijau & deltoid & satu & putih & tidak ada & kuning & intermediet \\
\hline IPB C343 & tidak ada & hijau & silidris & hijau & ovate & satu & putih & tidak ada & kuning & interm \\
\hline IPB C344 & tidak ada & hijau & silidris & hijau & ovate & satu & putih & ada & biru pucat & intermediet \\
\hline IPB C345 & tidak ada & hijau & silidris & hijau & ovate & satu & putih & tidak ada & kuning & intermediet \\
\hline IPB C348 & tidak ada & hijau & silidris & hijau muda & ovate & satu & putih & ada & kuning & intermediet \\
\hline IPB C349 & tidak ada & hijau & silidris & hijau & ovate & satu & putih & tidak ada & kuning & intermediet \\
\hline IPB C350 & tidak ada & hijau & silidris & hijau & deltoid & satu & putih & tidak ada & lainnya & intermediet \\
\hline
\end{tabular}

Keterangan: A1: Pewarnaan antosianin pada hipokotil bibit; A2: seedling warna hipokotil; A3: bentuk batang; A4: warna daun; A5: bentuk daun; A6: jumlah bunga per axil ; A7: warna mahkota; A8: pewarnaan antosianin pada anter A9: warna anter; A10: tepi kelopak

tidak terdapat pewarnaan antosianin. Karakter warna anter (A9) sebagian besar berwarna kuning kecuali untuk genotipe IPB C289, IPB C295, IPB C335, IPB C337, dan IPB C344 berwarna hijau pucat. Genotipe IPB C321, IPB C331, IPB C332 berwarna ungu. Karakter tepi kelopak (A10) sebagian besar termasuk dalam kategori intermediet. Genotipe IPB C190 dan IPB C289 termasuk kategori keseluruhan. Genotipe IPB C285 termasuk dentate. Tabel 4 merupakan karakter kualitatif pada buah cabai. Karakter sisi kelopak (A11) sebagian besar termasuk dalam kategori membungkus hanya beberapa genotipe yang tidak membungkus (IPB C190, IPB C289, IPB C290, IPB C295, IPB C321, IPB C344, IPB C348 dan IPB C349). Karakter warna buah sebelum masak (A12) sebagai besar genotipe berwarna putih kehijauan. Genotipe IPB C331 dan IPB C332 berwarna hijau. Genotipe yang memiliki warna buahnya kuning diantaranya IPB C190, IPB C285, IPB C289, IPB C290, IPB C295, IPB C321, IPB C348 dan IPB C349. Cabai rawit sebagian besar kedudukan buah atau posisi buah (A13) adalah tegak. Ada juga posisi buahnya horizontal dan merunduk. Genotipe yang kedudukan buahnya horizontal adalah IPB C331, IPB C332, IPB C334, IPB C335, dan IPB C337. Genotipe yang termasuk merunduk atau drooping yaitu IPB C339, IPB C341, IPB C343 dan IPB C350. Karakter bentuk buah (A14) sebagian besar termasuk dalam kategori moderately triangular. Genotipe IPB C190, IPB C289, IPB C345 bentuk buahnya termasuk trapezoidal. Genotipe IPB C285, dan IPB C348 bentuk buah hornshaped. GenotipeIPB C290, IPB C334, IPB C339, IPB C343 dan IPB C349 bentuk buahnya narrowly triangular.

\section{Karakter Kuantitatif}

Karakter kuantitatif pada tanaman cabai yang diamati diantaranya karakter tinggi tanaman, lebar tajuk, bobot per buah, panjang buah, diameter buah, umur berbunga, umur panen, jumlah buah per tanaman dan bobot buah per tanaman. Tabel 4 merupakan rekapitulasi nilai koefisien keragaman dan kuadrat tengah karakter kuantitatiif. Genotipe berpengaruh sangat nyata pada semua karakter kecuali pada karakter umur panen berpengaruh nyata.

Nilai tengah keragaan untuk semua karakter kuantitatif disajikan pada Tabel 5. Genotipe IPBC 339 merupakan genotipe paling tinggi untuk karakter tinggi tanaman tidak berbeda dengan genotipe IPB C331, IPBC 341, IPB C342, IPB C348 dan IPB C350. Tanaman yang memiliki lebar tajuk paling besar adalah genotipe IPBC339 (106.71 $\mathrm{cm})$ sedangkan tanaman yang paling kecil tajuknya yaitu genotipe IPBC285 $(65.25 \mathrm{~cm})$. Tinggi tanaman dan lebar 
Tabel 4. Karakter kualitatif pada morfologi tanaman cabai rawit

\begin{tabular}{|c|c|c|c|c|}
\hline Genotipe & A11 & A12 & A13 & A14 \\
\hline IPB C190 & tidak membungkus & kuning & tegak & trapezoidal \\
\hline IPB C285 & membungkus & kuning & tegak & hornshaped \\
\hline IPB C289 & tidak membungkus & kuning & tegak & trapezoidal \\
\hline IPB C290 & tidak membungkus & kuning & tegak & narrowly triangular \\
\hline IPB C295 & tidak membungkus & kuning & tegak & moderately triangular \\
\hline IPB C321 & tidak membungkus & kuning & tegak & moderately triangular \\
\hline IPB C331 & membungkus & hijau & horizontal & moderately triangular \\
\hline IPB C332 & membungkus & hijau & horizontal & moderately triangular \\
\hline IPB C334 & membungkus & putih kehijauan & horizontal & narrowly triangular \\
\hline IPB C335 & membungkus & putih kehijauan & horizontal & moderately triangular \\
\hline IPB C337 & membungkus & putih kehijauan & horizontal & moderately triangular \\
\hline IPB C339 & membungkus & putih kehijauan & merunduk & narrowly triangular \\
\hline IPB C341 & membungkus & putih kehijauan & merunduk & moderately triangular \\
\hline IPB C342 & membungkus & putih kehijauan & tegak & moderately triangular \\
\hline IPB C343 & membungkus & putih kehijauan & merunduk & narrowly triangular \\
\hline IPB C344 & tidak membungkus & putih kehijauan & tegak & moderately triangular \\
\hline IPB C345 & membungkus & putih kehijauan & tegak & trapezoidal \\
\hline IPB C348 & tidak membungkus & kuning & tegak & hornshaped \\
\hline IPB C349 & tidak membungkus & kuning & tegak & narrowly triangular \\
\hline IPB C350 & membungkus & putih kehijauan & merunduk & moderately triangular \\
\hline
\end{tabular}

Keterangan: A11: Sisi kelopak, A12:Warna buah sebelum masak, A13: Kedudukan buah, A14; Bentuk buah dalam penampang membujur

tajuk merupakan karakter penting karena ukuran tanaman mempengaruhi secara langsung apakah akan dibudidayaan dalam pot atau lading (Padilha et al., 2016). Pedo et al., (2013) menyatakan bahwa lebar tajuk merupakan karakter penting terhadap tingkat fotosintesis, yang mempengaruhi secara tidak langsung dalam produksi tanaman. Karakter buah yang diamati diantaranya bobot per buah, panjang buah, dan diameter buah. Genotipe IPB C341 merupakan genotipe dengan bobot per buah paling besar (3.24 g) sedangkan genotipe IPB C332 merupakan genotipe dengan bobot buah paling kecil (0.62 g). Karakter panjang buah berkisar antara 2.39-5.49 cm. Genotipe paling panjang ukuran buahnya adalah IPB C350 sedangkan ukuran paling pendek genotipe IPB C332. Diamater buah cabai rawit paling besar adalah pada genotipe IPB C289 (16.70 mm) sedangkan genotipe paling kecil genotipe IPB C332 (7.26 $\mathrm{mm})$. Karakter seperti diameter buah, tebal dinding buah, tinggi tanaman dan jumlah buah per tanaman adalah faktor yang paling berpengaruh terhadap hasil panen (Cankaya et al., 2010).

Umur berbunga pada tanaman cabai rawit berkisar antara 47.67 -63.67 hari setelah tanam (HST). Genotipe IPBC337 merupakan genotipe dengan umur berbunga paling pendek (47.67 HST) sedangkan genotipe yang paling lama umur berbunga adalah genotipe IPB C342 (63.67 HST). Umur panen berkisar antara 88-137.67 HST. Genotipe IPB C337 merupakan genotipe dengan umur panen yang cepat yaitu 88 HST, namun tidak berbeda dengan genotipe IPB C321 (91.67 HST). Genotipe dengan umur panenpaling lama yaitu genotipe IPB C285 (137.67 HST). Padilha et al. (2016) menyatakan bahwa umur panen merupakan aspek penting dalam pengembangan untuk varietas baru dengan siklus umur lebih pendek atau lebih panjang sehingga petani memiliki banyak pilihan untuk menanam di lahan

Karakter jumlah buah per tanaman berkisar antara 28.88-250.96 buah. Jumlah buah pertanaman paling banyak terdapat pada genotipe IPB C337 dan paling sedikit genotipe IPB C190. Bobot buah per tanaman merupakan potensi dari bobot buah yang dihasilkan dari satu tanaman cabai, semakin tinggi bobot buah total per tanaman ini maka hasil yang akan diperoleh dalam skala area penanaman per hektarnya akan semakin tinggi. Kisaran potensi bobot buah per tanaman pada yaitu 27.44-209.7 $\mathrm{g} \mathrm{tan}^{-1}$. Genotipe IPB C341 merupakan cabai yang memiliki potensi bobot buah per tanaman paling tinggi (209.7 $\left.\mathrm{g} \mathrm{tan}^{-1}\right)$ sementara genotipe IPB C285 merupakan genotipe yang potensinya sebesar $27.44 \mathrm{~g} \mathrm{tan}^{-1}$.

\section{Analisis Gerombol Karakter Kualitatif dan Kuantitatif}

Analisis gerombol bertujuan untuk mengelompokkan data (pengamatan) ke dalam beberapa kelas (gerombol) dengan kriteria pengelompokan berdasarkan pada ukuran ketidakmiripan (Yunianti et al., 2007). Karakteristik 
pengamatan dalam suatu gerombol memiliki tingkat ketidakmiripan yang rendah, sedangkan antar gerombol memiliki tingkat ketidakmiripan yang tinggi (Mattjik dan Sumertajaya, 2011). Hasil analisis gerombol yang dilakukan pada 20 genotipe cabai rawit dengan menggunakan 14 karakter kualitatif dan 9 karakter kuantitatif seperti pada Gambar 1 menunjukkan terdapat 4 kelompok pada koefisien ketidakmiripan $40 \%$. Kelompok 1 terdapat 2 genotipe yaitu

Tabel 5. Rekapitulasi nilai koefisien keragaman dan kuadrat tengah pada karakter vegetatif dan generatif 20 genotipe cabai rawit

\begin{tabular}{clcc}
\hline No & \multicolumn{1}{c}{ Karakter } & KK (\%) & KT genotipe \\
\hline 1 & Tinggi tanaman & 9.85 & $274.59^{* *}$ \\
2 & Lebar tajuk & 8.62 & $339.22^{* *}$ \\
3 & Bobot per buah & 23.37 & $1.48^{* *}$ \\
4 & Panjang buah & 11.85 & $1.84^{* *}$ \\
5 & Diameter buah & 10.84 & $21.29^{* *}$ \\
6 & Umur berbunga & 5.27 & $48.26^{* *}$ \\
7 & Umur panen & 15.48 & $679.04^{*}$ \\
8 & Jumlah buah per tanamaan & 18.48 & $8257.73^{* *}$ \\
9 & Bobot buah per tanaman & 21.95 & $7529.46^{* *}$ \\
\hline
\end{tabular}

Keterangan: tn, $*, * *=$ berturut-turut hasil uji $\mathrm{F}$ tidak nyata pada taraf $5 \%$, nyata pada taraf $5 \%$ dan nyata pada taraf $1 \%$, KK $=$ koefisien keragaman

Tabel 6. Nilai rataan karakter kuantitatif pada 20 genotipe cabai rawit

\begin{tabular}{|c|c|c|c|c|c|c|c|c|c|}
\hline Genotipe & $\mathrm{TT}(\mathrm{cm})$ & $\mathrm{LT}(\mathrm{cm})$ & $\mathrm{BB}(\mathrm{g})$ & PB $(\mathrm{cm})$ & $\mathrm{DB}(\mathrm{mm})$ & UB (HST) & UP (HST) & JB (buah) & BBT (gtan-1) \\
\hline IPB C190 & $93.78 \mathrm{~cd}$ & 101.18abcd & $2.20 \mathrm{bcdef}$ & $2.93 \mathrm{fg}$ & $15.88 \mathrm{ab}$ & 57.33 bcde & 127.33abcd & $28.88 \mathrm{c}$ & $44.23 \mathrm{de}$ \\
\hline IPB C285 & $92.85 \mathrm{~d}$ & $65.25 \mathrm{~h}$ & $1.01 \mathrm{hij}$ & $3.36 \mathrm{def}$ & $8.41 \mathrm{hi}$ & $59.67 \mathrm{abc}$ & $137.67 \mathrm{a}$ & $45.71 \mathrm{bc}$ & $27.44 \mathrm{e}$ \\
\hline IPB C289 & $99.40 \mathrm{bcd}$ & $89.32 \mathrm{cdef}$ & $2.60 \mathrm{abc}$ & 3.33def & $16.70 \mathrm{a}$ & $54.67 \mathrm{cdef}$ & $95.33 \mathrm{cdef}$ & $45.06 \mathrm{bc}$ & $55.99 \mathrm{cde}$ \\
\hline IPB C290 & $107.97 \mathrm{bcd}$ & $90.46 \mathrm{bcdef}$ & $1.77 \mathrm{defgh}$ & $3.74 \mathrm{cdef}$ & $12.46 \mathrm{~cd}$ & $49.67 \mathrm{fg}$ & 113.67abcdef & $97.67 b c$ & 68.41 bcde \\
\hline IPB C295 & $93.33 d$ & $76.30 \mathrm{fgh}$ & $1.36 \mathrm{ghij}$ & $3.18 \mathrm{fg}$ & $10.90 \mathrm{defg}$ & $61.33 \mathrm{ab}$ & 110.33abcdef & $73.71 b c$ & $51.35 \mathrm{cde}$ \\
\hline IPB C321 & $92.68 \mathrm{~d}$ & $74.51 \mathrm{gh}$ & $1.42 \mathrm{ghi}$ & $3.41 \mathrm{def}$ & $10.44 \mathrm{defgh}$ & $49.67 \mathrm{fg}$ & $91.67 \mathrm{f}$ & $73.17 \mathrm{bc}$ & $41.85 \mathrm{e}$ \\
\hline IPB C331 & $110.71 \mathrm{abcd}$ & $88.91 \mathrm{cdefg}$ & $1.03 \mathrm{hij}$ & $3.28 \mathrm{ef}$ & 8.92ghi & $56.33 \mathrm{bcde}$ & $104.00 \mathrm{bcde}$ & $105.65 b c$ & $49.31 \mathrm{de}$ \\
\hline IPB C332 & $97.54 \mathrm{bcd}$ & 98.43abcd & $0.62 \mathrm{j}$ & $2.39 \mathrm{~g}$ & $7.26 \mathrm{i}$ & $57.33 \mathrm{bcde}$ & 106.67abcdef & $111.88 \mathrm{bc}$ & $31.27 \mathrm{e}$ \\
\hline IPB C334 & 109.10bcd & 94.17abcde & $1.89 \mathrm{cedfg}$ & $4.14 \mathrm{bcde}$ & $12.15 \mathrm{~cd}$ & $56.00 \mathrm{bcde}$ & 94.00efd & $141.40 \mathrm{bc}$ & 129.27abcd \\
\hline IPB C335 & $109.29 \mathrm{bcd}$ & 98.14abcd & 1.00hij & $3.14 \mathrm{fg}$ & 9.41 efghi & $54.00 \mathrm{cdef}$ & $92.67 \mathrm{efd}$ & $144.40 \mathrm{ab}$ & $73.09 \mathrm{bcde}$ \\
\hline IPB C337 & $101.44 \mathrm{bcd}$ & $96.55 \mathrm{abcd}$ & $1.37 \mathrm{ghij}$ & $3.42 \mathrm{def}$ & $11.07 \mathrm{defg}$ & $47.67 \mathrm{~g}$ & $88.00 \mathrm{f}$ & $250.96 \mathrm{a}$ & 129.51abcd \\
\hline IPB C339 & $129.10 \mathrm{a}$ & $106.71 \mathrm{a}$ & 1.55 fghi & $4.46 b c$ & 11.40def & $59.67 \mathrm{abc}$ & $128.67 \mathrm{abc}$ & $132.99 \mathrm{bc}$ & $143.99 \mathrm{ab}$ \\
\hline IPB C341 & $113.94 \mathrm{abc}$ & $102.36 \mathrm{abc}$ & $3.24 \mathrm{a}$ & $4.65 \mathrm{~b}$ & $16.03 \mathrm{ab}$ & $54.00 \mathrm{cdef}$ & $96.67 \mathrm{bcde}$ & $122.87 \mathrm{bc}$ & $209.7 \mathrm{a}$ \\
\hline IPB C342 & 117.76ab & $79.44 \mathrm{efg}$ & $0.85 \mathrm{ij}$ & $3.78 \mathrm{cdef}$ & $8.14 \mathrm{hi}$ & $63.67 \mathrm{a}$ & 118.67abcdef & $59.41 b c$ & $36.92 \mathrm{e}$ \\
\hline IPB C343 & $107.50 \mathrm{bcd}$ & 88.52 cedfg & $2.33 \mathrm{bcde}$ & $4.91 \mathrm{ab}$ & $11.60 \mathrm{de}$ & $53.67 \mathrm{def}$ & $98.67 \mathrm{bcde}$ & $128.63 b c$ & $149.7 \mathrm{ab}$ \\
\hline IPB C344 & 103.96bcd & $89.53 \mathrm{cdef}$ & $1.94 \mathrm{cdefg}$ & $4.09 \mathrm{bcde}$ & $12.39 \mathrm{~cd}$ & $54.67 \mathrm{cdef}$ & $97.33 \mathrm{bcde}$ & $135.70 b c$ & 135.17abc \\
\hline IPB C345 & $107.46 \mathrm{bcd}$ & $104.85 \mathrm{ab}$ & $2.50 \mathrm{bcd}$ & $4.20 \mathrm{bcd}$ & $14.09 \mathrm{bc}$ & $54.33 \mathrm{cdef}$ & 126.00abcde & $71.87 \mathrm{bc}$ & $106.34 \mathrm{bcde}$ \\
\hline IPB C348 & $114.15 \mathrm{abcd}$ & 93.00abcde & 1.69 efgh & $4.94 \mathrm{ab}$ & 10.39defgh & $55.00 \mathrm{cdef}$ & 109.00abcdef & $55.54 \mathrm{bc}$ & $56.21 \mathrm{cde}$ \\
\hline IPB C349 & $102.33 \mathrm{bcd}$ & $89.97 \mathrm{bcdef}$ & 1.28ghij & $4.30 \mathrm{bc}$ & 9.14fghi & $52.33 \mathrm{efg}$ & 117.00abcdef & $140.18 b c$ & $96.97 \mathrm{bcde}$ \\
\hline IPB C350 & $114.57 \mathrm{ab}$ & $85.82 \mathrm{defg}$ & $2.71 \mathrm{ab}$ & $5.49 \mathrm{a}$ & $12.43 \mathrm{~cd}$ & $59.00 \mathrm{abcd}$ & $130 \mathrm{ab}$ & $41.04 \mathrm{bc}$ & $55.13 \mathrm{cde}$ \\
\hline
\end{tabular}

Keterangan: $\quad \mathrm{TT}=$ tinggi tanaman, $\mathrm{LT}=$ lebar tajuk, $\mathrm{BB}=$ bobot per buah, $\mathrm{PB}=$ panjang buah, $\mathrm{DB}=$ diameter buah, $\mathrm{UB}=$ umur berbunga, $\mathrm{UP}=$ umur panen, $\mathrm{JB}=$ jumlah buah per tanaman dan $\mathrm{BBT}=$ bobot buah total $(\mathrm{BBT})$. Angka-angka yang diikuti dengan huruf yang sama pada kolom yang sama tidak berbeda nyata pada DMRT taraf $5 \%$. 


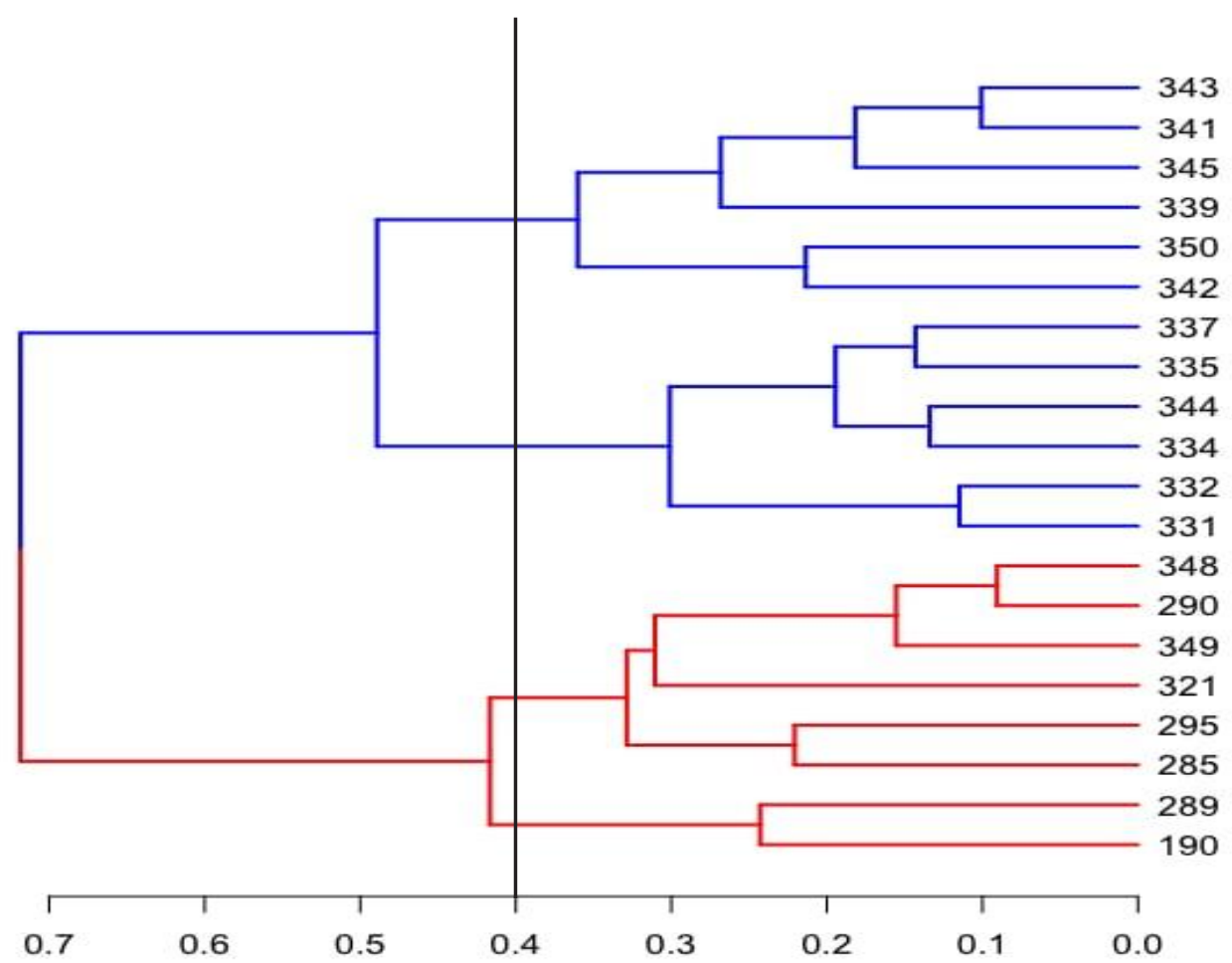

Gambar 1. Pengelompokkan 20 genotipe cabai rawit berdasarkan karakter kualitatif dan kuantitatif

IPB C190 dan IPB C 289, kelompok 2 terdiri dari 6 genotipe IPB C285, IPB C295, IPB C321, IPB C349, IPB C290 dan IPB C348, kelompok 3 terdiri dari 6 genotipe yaitu IPB C331, IPB C332, IPB C334, IPB C334, IPB C344, IPB C335 dan IPB C337, IPB C339, serta kelompok 4 terdiri dari 6 genotipe yaitu IPB C342, IPB C350, IPB C339, IPB C345, IPB C341 dan IPB C343.

\section{KESIMPULAN}

Genotipe IPB C341 merupakan genotipe yang mempunyai bobot per buah dan bobot buah per tanaman paling besar. IPB C350 merupakan genotipe yang memiliki ukuran buah paling panjang. IPB C337 merupakan genotipe dengan jumlah buah per tanaman paling banyak. Hasil analisis gerombol membagi ke dalam 4 kelompok yaitu kelompok 1 terdapat 2 genotipe terdiri dari IPB C190 dan IPB C289, kelompok 2 terdiri dari 6 genotipe IPB C285, IPB C295, IPB C321, IPB C349, IPB C290 dan IPB C348, kelompok 3 terdiri dari 6 genotipe yaitu IPB C331, IPB C332, IPB C334, IPB C334, IPB C344, IPB C335 dan IPB C337, IPB C339, dan kelompok 4 terdiri dari 6 genotipe yaitu IPB C342, IPB C350, IPB C339, IPB C345, IPB C341 dan IPB C343.

\section{UCAPAN TERIMAKASIH}

Terimakasih disampaikan kepada Kementerian Riset dan Teknologi RI yang telah membiayai penelitian ini melalui Hibah PUSNAS 2015 an. Prof. Dr. Ir. Anas Dinurrohman Susila, M.Si.

\section{DAFTAR PUSTAKA}

[BPS; DJH] Biro Pusat Statistik dan Direktorat Jenderal Hortikultura. 2014. Produktivitas Sayuran di Indonesia, 2010-2014. Biro Pusat Statistik dan Direktorat Jenderal Hortikultura. Jakarta.

[IPGRI] International Plant Genetic Resources Institute. 1995. Descriptors for Capsicum (Capsicum spp.). International Plant Genetic Resources Institute (IPGRI), Roma.

Sujinto, E., M. Dianawati. 2015. Produksi panen berbagai varietas unggul baru cabai rawit (Capsicum frutescens) di lahan kering Kabupaten Garut, Jawa Barat. Pros. Sem. Nas. Masy. Biodiv. Indon. 1: 874877.

Undang, Syukur M, Sobir. 2015. Identifikasi spesies cabai (Capsicum spp.) berdasarkan daya silang dan karakter morfologi. J. Agron. Indonesia. 43 (2): 118-125.

Yunianti, R., S. Sastrosumarjo, S. Sujiprihati, M. Surahman, S.H. Hidayat. 2007. Ketahanan dan keragaman genetik 22 genotipe cabai (Capsicum spp.) terhadap Phytophthora capsici Leonian. Bul. Agron.35: 103.

Sun, Y.L., I.L. Choi, Y.B Lee, K.Y. Choi, S.K. Hong, H.M. Kang. 2014. Molecular diversity and phylogentic analysis of Capsicum annuum varieties using the nrDNA ITS region. Scientia Horticulturae. 165:336343. 
Hill, T.A., H. Ashrafi, S.R. Chin Wo, J. Yao, K. Stoffel, M.J. Truco, A.V. Deynze. 2013. Characterization of Capsicum annuum genetic diversity and population structure based on parallel polymorphism discovery with a $30 \mathrm{~K}$ unigene Pepper Gene Chip. PloS One 2(8): 1-16.

Padilha, H.K.M, C.V. Sigales, J.C.B. Villela, R.A Valgas, R.L. Barbieri. 2016. Agronomic evaluation and morphological characterization of chili peppers (Capsicum annuum, Solanaceae) from Brazil. Australian Journal of Basic and Applied Sciences. 10(13): $63-70$
Pedo, T., T.Z. Aumonde, N.F. Lopes. 2013. Comparative analysis of growth between genotypes of pepper grown in greenhouse. Bioscience Journal, 29(1): $125-131$

Cankaya, S., A. Balkaya, O. Karaagac. 2010. Canonical correlation analysis for the determination of relationships between plant characters and yield components in red pepper (Capsicum annuum L. var. conoides (Mill.) Irish) genotypes. Spanish Journal of Agricultural Research 1(8): 67-73. 